\title{
Anti-GD2 Immunoliposomes for Targeted Delivery of the Survivin Inhibitor Sepantronium Bromide (YMI55) to Neuroblastoma Tumor Cells
}

\author{
Shima Gholizadeh ' Emmy M. Dolman ${ }^{2,3}$ - Rebecca Wieriks' • Rolf W. Sparidans ${ }^{4}$. \\ Wim E. Hennink' • Robbert J. Kok'
}

Received: 9 November 2017 / Accepted: 15 February 2018 / Published online: 7 March 2018

(C) The Author(s) 2018. This article is an open access publication

\begin{abstract}
Purpose Sepantronium bromide (YM155) is a hydrophilic quaternary compound that cannot be administered orally due to its low oral bioavailability; it is furthermore rapidly eliminated via the kidneys. The current study aims at improving the pharmacokinetic profile of YM155 by its formulation in immunoliposomes that can achieve its enhanced delivery into tumor tissue and facilitate uptake in neuroblastoma cancer cells. Methods PEGylated YM155 loaded liposomes composed of DPPG, cholesterol and DSPE-PEG 2000 were prepared via passive film-hydration and extrusion method. Targeted (i.e. immuno-)liposomes were prepared by surface functionalization with SATA modified monoclonal antidisialoganglioside (GD2) antibodies. Liposomes were characterized based on their size, charge, antibody coupling and YM155 encapsulation efficiency, and stability. Flow cytometry analysis and confocal microscopy were performed on IMR32 and KCNR neuroblastoma cell lines. The efficacy of
\end{abstract}

Electronic supplementary material The online version of this article (https://doi.org/l 0. I007/s I | 095-0 18-2373-x) contains supplementary material, which is available to authorized users.

Robbert J. Kok

r.j.kok@uu.nl

Department of Pharmaceutics, Utrecht Institute for Pharmaceutical Sciences Utrecht University

Utrecht, the Netherlands

2 Department of Oncogenomics, Academic Medical Center University of Amsterdam

Amsterdam, the Netherlands

3 Princess Maxima Center for Pediatric Oncology Utrecht, the Netherlands

4 Department of Chemical Biology and Drug Discovery, Utrecht Institute for Pharmaceutical Sciences Utrecht University

Utrecht, the Netherlands developed formulations were assessed by in-vitro toxicity assays. A pilot pharmacokinetic analysis was performed to assess plasma circulation and tumor accumulation profiles of the developed liposomal formulations.

Results YM155 loaded immunoliposomes had a size of $170 \mathrm{~nm}$ and zeta potential of $-10 \mathrm{mV}$, with an antibody coupling efficiency of $60 \%$ andYM 155 encapsulation efficiency of $14 \%$. Targeted and control liposomal formulations were found to have similar YM155 release rates in a release medium containing $50 \%$ serum. An in-vitro toxicity study on KCNR cells showed less toxicity for immunoliposomes as compared to free YM155. In-vivo pharmacokinetic evaluation of YM155 liposomes showed prolonged blood circulation and significantly increased half-lives of liposomal YM155 in tumor tissue, as compared to a bolus injection of free YM155. Conclusions YM155 loaded immunoliposomes were successfully formulated and characterized, and initial in-vivo results show their potential for improving the circulation time and tumor accumulation of YM155.

KEY WORDS immunoliposomes · neuroblastoma cells . sepantronium bromide (YMI55) · targeted delivery

$\begin{array}{ll}\text { ABBREVIATIONS } \\ \text { Ab } & \text { Antibodies } \\ \text { ACN } & \text { Acetonitrile } \\ \text { AUC } & \text { Area under curve } \\ \text { BIRC5 } & \begin{array}{l}\text { Baculoviral inhibitor of apoptosis } \\ \text { repeat-containing 5' }\end{array} \\ \text { BSA } & \text { Bovine serum albumin } \\ \text { CA } & \text { Compartmental analysis } \\ \text { Chol } & \text { Cholesterol } \\ \text { CLSM } & \text { Confocal laser scanning microscope } \\ \text { CNS } & \text { Central nervous system } \\ \text { DAPI } & \text { 4',6-Diamidino-2-phenylindole }\end{array}$




\begin{tabular}{|c|c|}
\hline DLS & Dynamic light scattering \\
\hline DMEM & Dulbecco's Modified Eagle's Medium \\
\hline DPPC & $\begin{array}{l}\text { 1,2-dipalmitoyl-sn-glycero-3- } \\
\text { phosphocholine }\end{array}$ \\
\hline DSPE-PEG 2000 & $\begin{array}{l}\text { 1,2-distearoyl-sn-glycero-3- } \\
\text { phosphoethanolamine-N- } \\
\text { [methoxy(polyethylene glycol)-2000] }\end{array}$ \\
\hline DSPE-PEG $2000-M a l$ & $\begin{array}{l}\text { 1,2-distearoyl-sn-glycero-3 } \\
\text { phosphoethanolamine-N } \\
\text { [maleimide(polyethylene glycol)-2000] }\end{array}$ \\
\hline DTA & Ethylenediaminetetraacetic acid \\
\hline-7 & Encapsulation efficiency \\
\hline EPR & Enhance permeability and retention \\
\hline FACS & Fluorescence activated cell sorting \\
\hline FCS & Fetal calf serum \\
\hline FITC & Fluorescein isothiocyanate \\
\hline HBS & Hepes buffered saline \\
\hline HRP & Horseradish peroxidase \\
\hline $\begin{array}{l}1 C_{50} \\
\lg G\end{array}$ & $\begin{array}{l}\text { Half maximal inhibitory concentration } \\
\text { Immunoglobulin G }\end{array}$ \\
\hline LC-MS/MS & $\begin{array}{l}\text { Liquid chromatography-tandem } \\
\text { mass spectrometry }\end{array}$ \\
\hline $\mathrm{MFI}$ & Mean fluorescence intensity \\
\hline MPS & Mononuclear phagocyte system \\
\hline NB & Neuroblastoma \\
\hline NCA & Non-compartmental analysis \\
\hline NEAA & Non-essential amino acids \\
\hline OCT & Organic cation transporter \\
\hline PEG & Polyethyleneglycol \\
\hline PBS & Phosphate buffered saline \\
\hline PK & Pharmacokinetic \\
\hline Rho-PE & $\begin{array}{l}\text { 1,2-dimyristoyl-sn-glycero-3- } \\
\text { phosphoethanolamine-N- } \\
\text { (lissamine rhodamine-B sulfonyl) }\end{array}$ \\
\hline SATA & N-succinimidyl S-acetylthioacetate \\
\hline SDS-PAGE & $\begin{array}{l}\text { Sodium dodecyl sulphate } \\
\text { polyacrylamide gel electrophoresis }\end{array}$ \\
\hline $4 / 2$ & Half life \\
\hline TBS-T & $\begin{array}{l}\text { Tris-buffered saline containing } \\
0.1 \% \text { Tween- } 20\end{array}$ \\
\hline $1 L$ & Total lipid \\
\hline UPLC & $\begin{array}{l}\text { Ultra performance liquid } \\
\text { chromatography }\end{array}$ \\
\hline & Ultraviolet \\
\hline
\end{tabular}

\section{INTRODUCTION}

Neuroblastoma (NB) is an aggressive malignancy of the sympathetic nervous system and is the most frequently occurring type of solid extracranial tumor in children (1). Although the survival rate in low-risk patients is currently over $90 \%$, children with high-risk neuroblastoma currently have a very poor prognosis.
For these patients, the 5 -year disease free survival rate is between $25 \%-35 \%$, despite many patients undergoing aggressive multi-modality therapies (i.e. combinations of chemotherapy, surgery, stem cell rescue and radiation therapy) (2). This highlights the urgent need for new therapeutic strategies $(1,3,4)$.

The pathology of neuroblastoma (as well as most other types of cancer) is complex and differs between individual patients. Anti-apoptotic proteins have been shown to play a role in tumor development, thus making such proteins promising drug targets. One of these proteins is survivin, which is encoded by the 'baculoviral inhibitor of apoptosis repeatcontaining 5' (BIRC5) gene. Over-expression of the survivinencoding gene has been shown to correlate strongly to a poor patient prognosis, metastatic spread and (increased) resistance to chemotherapy (5). Hence, survivin inhibitors could potentially be used in neuroblastoma treatment, especially for high risk patients with poor prognosis (6,7). Anti-BIRC5 antisense based therapies such as gataparsen sodium (LY2181308) and small molecular inhibitors of anti-apoptotic proteins are currently being tested in phase I/II clinical trials (8-10).

One of the promising small molecular inhibitors of survivin is sepantronium bromide (YM155) of which the structure is shown in Fig. 1 (11). Recent phase I/II 'single agent' clinical trials have shown acceptable toxicity in patients with advanced solid malignancies $(10,12)$. The physicochemical and pharmacological properties of YM155 are listed in Table I. Due to the hydrophilicity and permanent cationic charge on one of the nitrogen atoms of the molecule, YM155 is rapidly eliminated via organic cation transporter (OCT) mediated excretion in bile and urine. Because of this, YM155 has a short plasma half-life of approximately $1-2 \mathrm{~h}$, as determined in pharmacokinetic measurements in mice and rats $(13,14)$. The rapid elimination of YM155 dictates administration as intravenous infusion rather than intravenous bolus injection $(12,15)$.

Nano-encapsulation technologies and application of the resulting so-called nanomedicines in health care have received

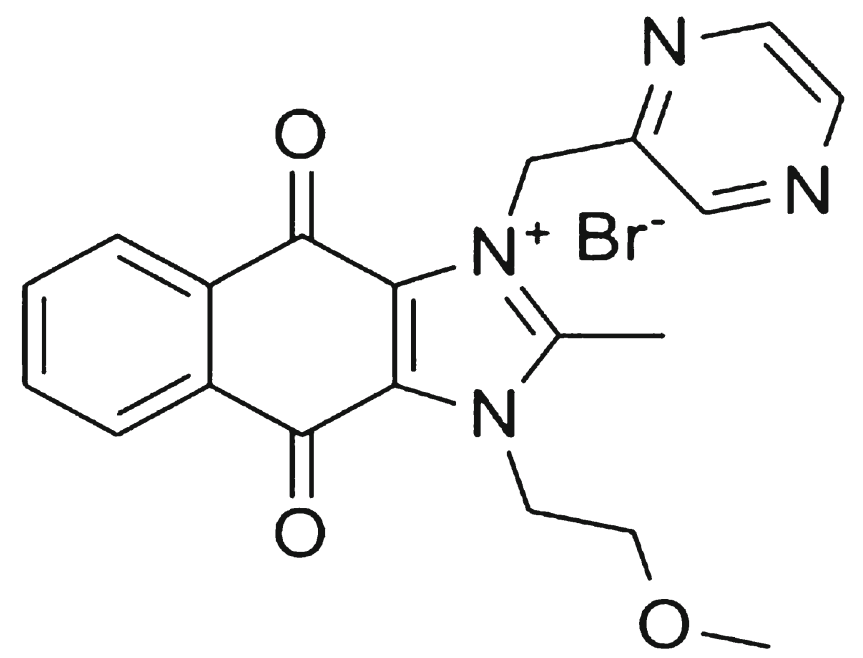

Fig. I Molecular structure of Sepantronium bromide (YMI 55). 
Table I Characteristics of YMI 55

\begin{tabular}{ll} 
Molecular weight & $443,3 \mathrm{~g} / \mathrm{mol}$ (Bromide salt) \\
\hline LogP & -3.7 \\
pKa & 5.3 \\
Solubility in water & At least $0,5 \mathrm{mg} / \mathrm{ml}$ \\
IC $_{50}$ & Low $\mathrm{nM}$ range for most neuroblastoma cell lines
\end{tabular}

much attention in recent years, in particular for application in cancer therapy $(16,17)$. Long circulating nanomedicines such as PEGylated liposomes can improve tumor drug delivery by virtue of the enhance permeability and retention (EPR) effect, i.e. the accumulation and retention of nanocarriers in the tumor site due to differences between normal vasculature and tumor blood vessels (18). Thus, the rapid elimination of YM155 and its poor pharmacokinetic properties can potentially be improved by encapsulating the YM155 molecules in a nanocarrier that can prevent renal excretion of the compound. In recent studies, such a PEGylated liposomal dosage form of YM155 has been introduced and studied in rodent cancer models for tumor drug uptake and efficacy $(19,20)$. We now propose a novel immunoliposomal formulation for YM155, which can further improve its delivery to neuroblastoma.

Targeted liposomes (immunoliposomes) have been modified with ligands such as antibodies (Ab) that bind to cell-surface exposed receptors on target cells. Such a binding of the nanomedicine to receptors can be an efficient strategy to facilitate the intracellular delivery of drugs into target cells, which can further enhance their specificity for the targeted cell type $(21,22)$. Disialoganglioside GD2 is an attractive target for an immunoliposome based strategy since GD2 is extensively expressed by neuroblastoma tumor cells (23-26), while it is virtually absent in nonmalignant tissues outside the central nervous system (CNS) (27). GD2-positive tumor cells can be recognized specifically by anti-GD2 antibodies (Ab) or anti-GD2 $\mathrm{Ab}$ functionalized nanoparticles (28). Chimeric and humanized anti-GD2 antibodies have been investigated for immunotherapy, tumor vaccination and as targeting ligand for drug delivery purposes (29). Although GD2 is expressed in neurons, the human brain is protected from parenteral anti-GD2 Ab and antiGD2 decorated nanoparticles by the blood-brain barrier.

In this study, we investigate the formulation of YM155 in GD2-targeted immunoliposomes for the specific delivery of YM155 to neuroblastoma tumor cells. The obtained formulation was evaluated for its in-vitro stability and YM155 release kinetics at different release conditions. The cell specific binding and uptake of the liposomal formulations (i.e. targeted and nontargeted control) were analyzed in cultured NB tumor cells, followed by an in-vitro efficacy evaluation of the YM155 liposomes and free YM155. Finally, a pharmacokinetic pilot study was conducted to investigate the plasma half-life and tumor accumulation of the YM155 immunoliposomes in mice.

\section{MATERIALS AND METHODS}

\section{Materials}

The lipids 1,2-dipalmitoyl-sn-glycero-3-phosphocholine (DPPG), 1,2-distearoyl-sn-glycero-3 phosphoethanolamine$\mathrm{N}$-[maleimide(polyethylene glycol)-2000] (DSPE-PEG ${ }_{2000^{-}}$ Mal), 1,2-distearoyl-sn-glycero-3-phosphoethanolamine$\mathrm{N}$-[methoxy(polyethylene glycol)-2000] (DSPE-PEG 2000 ) and 1,2-dimyristoyl-sn-glycero-3-phosphoethanolamine$\mathrm{N}$-(lissamine rhodamine-B sulfonyl) (Rho-PE) were purchased from Avanti Polar Lipids (Alabaster AL, USA). Cholesterol (Chol) was obtained from Sigma Aldrich (St. Louis MO, USA). Sepantronium bromide (YM155) was purchased from Bio-connect (Huissen, The Netherlands). Antidisialoganglioside GD2 (Anti-GD2) antibody was obtained from BD Pharmingen (Alphen aan den Rijn, The Netherlands). N-succinimidyl S-acetylthioacetate (SATA) and Hoechst 33,342 Fluorescent Stain were obtained from Thermo Fischer Scientific (Landsmeer, The Netherlands).4',6-Diamidino-2-phenylindole (DAPI) was obtained from Roche (The Netherlands). FluorSave mounting agent was obtained from Merck Millipore (San Diego, CA, USA). All chemicals used were analytical grade unless otherwise stated. Cell culture media and supplements were obtained from Gibco laboratories (Gaithersburg, United states). Fetal calf serum (FCS) was obtained from Sigma Aldrich.

\section{Preparation of Liposomes}

Immunoliposomes were prepared from a mixture of DPPC, Cholesterol, DSPE-PEG 2000 and DSPE-PEG ${ }_{2000}-\mathrm{Mal}$ in molar ratios of 1.36:1.36:0.14:0.14, based on prior immunoliposomal formulations developed in our department (30). Control liposomes consisted of DPPC, Cholesterol and DSPE-PEG ${ }_{2000}$ in molar ratios of 1.36:1.36:0.28. Fluorescently labeled liposomes were prepared by adding rhodamine-PE to the lipid mixture at $0.2 \mathrm{~mol} \%$ of total lipid (TL). Lipids were dissolved in chloroform: methanol $(9: 1, v / \mathrm{v})$ and to a final concentration of $90 \mathrm{mM}$ TL. YM155 was codissolved with the lipid mixture at a concentration of $0.25 \mu \mathrm{mol} / \mu \mathrm{mol} \mathrm{TL}$. Organic solvents were removed using a rotary evaporator and subsequent drying under a nitrogen flow. The resulting drug-lipid film was hydrated by adding $3 \mathrm{ml}$ of HBS buffer $\mathrm{pH} 7.4(10 \mathrm{mM}$ Hepes containing $135 \mathrm{mM} \mathrm{NaCl}$ ). Unilamellar liposomes were prepared by multiple extrusion steps over polycarbonate membranes (Nuclepore, Pleasanton, CA, USA) at decreasing pore size range (from 0.4 to $0.1 \mu \mathrm{m}$ ). Next, targeted liposomes (but not control liposomes) were reacted with Sata-anti-GD2 antibody at a final concentration of $30 \mu \mathrm{g} / \mu \mathrm{mol} \mathrm{TL}$ ( $2 \mathrm{mg} / \mathrm{ml}$ antibody) that had been deprotected with hydroxylamine $0.5 \mathrm{M}$ for 
$45 \mathrm{~min}$ prior to its addition to the liposomes. Coupling of Sacetylthioacetyl (SATA) to anti-GD2 (8:1 SATA:Ab mol:mol ratio) was performed as described previously (31). Remaining non-reacted antibody and non-encapsulated YM155 were removed by ultracentrifugation at $60,000 \mathrm{~g}$ at $4^{\circ} \mathrm{C}$ for $30 \mathrm{~min}$ and resuspension of liposomes in $3 \mathrm{ml}$ HBS This step was repeated in three times. After the final purification step, liposomes were stored under nitrogen atmosphere at $4^{\circ} \mathrm{C}$ in the dark for a maximum of 4 weeks prior to usage.

\section{Characterization of Liposomes}

Liposome size and polydispersity was measured using dynamic light scattering (DLS) on an ALV CGS-3 system (Malvern Instruments, Malvern, UK). Zeta- $(\zeta)$ potential of liposomes was measured using a Malvern Zetasizer Nano-Z (Malvern Instruments) with universal ZEN 1002 dip cells and DTS (Nano) software. The total lipid concentration was determined according to Rouser (32). YM155 content of the liposomes was determined from $100 \mu \mathrm{l}$ aliquots which were disrupted by diluting in $300 \mu \mathrm{l}$ of acetonitrile (ACN). YM155 content was measured with a UPLC Waters Acquity system (Waters Corporation, Milford, MA, USA) equipped with Acquity UPLC ${ }^{B}$ BEH C18, $1.7 \mu \mathrm{m}$ column $(2.1 \times 50 \mathrm{~mm})$ thermostated at $50^{\circ} \mathrm{C}$ and a UV detector (Waters Corporation, Milford, MA, USA) operated at $252 \mathrm{~nm}$. The gradient mobile phase was operated at a flow rate of $0.5 \mathrm{ml} /$ min and consisted of $5 \%(v / v)$ ACN in water containing in total $0.1 \%(\mathrm{v} / \mathrm{v})$ trifluoroacetic acid (solvent $\mathrm{A}$ ) and $100 \%$ ACN containing $0.1 \%$ trifluoroacetic acid (solvent $\mathrm{B}$ ). YM155 encapsulation efficiency (EE \%) was calculated from the determined YM155/TL ratio versus the initial drug/TL ratio. Conjugation of anti-GD2 to DSPE-PEG $2000-$ Malwas confirmed by western blotting using anti-mouse IgG immunodetection. In brief, reduced samples were subjected to SDS-PAGE using 4-12\% gradient NuPAGE Novex BisTris mini-gel (Thermo Fischer Scientific). Samples were electrotransferred onto a nitrocellulose membrane via an iBlot Dry Blotting system (Invitrogen). Next, the membrane was blocked with $5 \%(w / v)$ BSA in Tris-buffered saline containing $0.1 \%$ Tween-20 (TBS-T) and incubated with goatanti mouse-IgG secondary antibody conjugated to horseradish peroxidase (HRP) (Thermo Fischer Scientific), diluted $1: 1000$ in $5 \%$ BSA in TBS-T. Proteins were visualized and detected using SuperSignal West Femto Chemiluminescent Substrate (ThermoFischer Scientific) and a Gel Doc imaging system equipped with a XRS camera and Quantity One analysis software (Bio-Rad, Hercules, CA, USA). Coupling of antiGD2 to targeted liposomes was quantified were further characterized by micro-BCA assay (Pierce Biotechnology, Rockford, IL, USA) using mouse IgG (Sigma Aldrich) as calibration standards. Antibody coupling degree (antibody/liposome; ) was calculated using geometric arguments according to Adrian (33) using the following formula: $=\pi /$ $6 \times \mathrm{C}_{\mathrm{Ab}} \times\left(3 \mathrm{~d}_{\mathrm{bl}} \times \mathrm{R}^{2}-3 \mathrm{R} \times \mathrm{d}_{\mathrm{bl}}{ }^{2}+\mathrm{d}_{\mathrm{bl}}{ }^{3}\right) \times \mathrm{M}_{\mathrm{ab}}{ }^{-1} \times \mathrm{V}_{\mathrm{Ls}}{ }^{-1}$, in which $\left(\mathrm{C}_{\mathrm{Ab}}\right)$ is the measured concentration of coupled antibody ( $\mathrm{g} / \mathrm{mol} \mathrm{TL}),\left(\mathrm{M}_{\mathrm{Ab}}\right)$ is the molecular mass of the antibody, $(\mathrm{R})$ is the average diameter of liposomes $(\mathrm{nm})$ of the spherical liposomes and $\left(\mathrm{V}_{\mathrm{Ls}}\right)$ and $\left(\mathrm{d}_{\mathrm{bl}}\right)$ represent the specific lipid volume and lipid bilayer thickness, respectively.

\section{Storage Retention of YMI55 Liposomes}

The storage retention of encapsulated YM155 in liposomal formulations in HBS buffer was studied at $4^{\circ} \mathrm{C}$ for a total duration of 4 weeks. At 0, 5, 10, 20 and 30 days samples were collected in duplicate. Released (nonencapsulated) YM155 was separated from liposomal YM155 by ultrafiltration using Vivaspin centrifugal concentrators with a molecular weight cut-off membrane of $10 \mathrm{kDa}$ (Sartorius AG, Aubagne, France) for $5 \mathrm{~min}$ at $4000 \mathrm{~g}$ at $4^{\circ} \mathrm{C}$. YM155 was determined in both the filtrate (free YM155, released fraction) and the remaining fraction in the upper compartment of the Vivaspin device (total YM155, free and liposomal fraction) which represented at least $70 \%$ of the starting volume. The collected samples (both fractions) from each time point were stored in the dark at $4^{\circ} \mathrm{C}$ for further analysis. Aliquots of $50 \mu \mathrm{l}$ were taken and diluted in $150 \mu \mathrm{l} \mathrm{ACN}$, centrifuged at 22,000 $\mathrm{g}$ for $10 \mathrm{~min}$ at $4^{\circ} \mathrm{C}$ and subjected to UPLC analysis as described above. Experiments were repeated two times with individually prepared batches of liposomes. Particle size and polydispersity were studied at the beginning and end of the study by DLS as described above.

\section{In-Vitro Release of YMI 55 from Liposomes}

Release studies were conducted to study the influence of serum proteins and temperature on retention of YM155 in liposomes. Aliquots of anti-GD2 targeted and control liposomes with a final YM155 concentration of 25-30 $\mu \mathrm{M}$ were prepared by diluting the stock solutions prepared for each batch with incubation media consisting of either HBS buffer, 5\% bovine serum albumin (BSA) in HBS buffer, or pooled female mouse serum containing EDTAdisodium (Seralab Laboratories, Haywards Heath, UK) diluted 1:1 with HBS buffer. Samples were incubated at either $37^{\circ} \mathrm{C}$ or $4^{\circ} \mathrm{C}$ while gently shaking on a roller bench for a total duration of $24 \mathrm{~h}$. At pre-determined time periods of 6, 12 and $24 \mathrm{~h}$, samples were removed from the incubators and concentrations of released YM155 and total YM155 were determined as described above. Experiments were repeated two times with individually prepared batches of liposomes. YM155 retention in liposomes at each time point was calculated after correction for low levels $(<5 \%)$ of free YM155 at the beginning of 
the incubations. The YM155 release data were fitted with zero-order or first order kinetic models, thereby using the following formulas:

Zero-order kinetics : $M_{t} / M_{0}=-k^{*} t$

First-order kinetics : $M_{t} / M_{0}=e^{-k^{*} t}$

Where $M_{0}$ is the amount of encapsulated YM155 at the start of the incubation and $M_{t}$ is the amount of encapsulated YM155 at each time point; $k$ is the release rate constant. The release rate constants $(k)$ reported in this work are calculated from first-order kinetics fits to experimental release data. The calculated release rate constants allow a quantitative comparison of the experimental YM155 release profiles of the (liposomal) formulations under the various conditions.

\section{Culturing of Tumor Cell Lines}

Neuroblastoma tumor cell lines KGNR, IMR32 and WiDR colon adenocarcinoma cells were obtained from ATCCTM. Cells were cultured in Dulbecco's Modified Eagle's Medium (DMEM) containing D-glucose $(4.5 \mathrm{~g} / \mathrm{L})$ and $2 \mathrm{mM}$ glutamate, without pyruvate, and supplemented with $10 \%$ fetal calf serum (FCS), 1\% MEM Non-Essential Amino Acids (NEAA) and 1\% L-Glutamine. Cells from passage 5 to 7 were seeded one day before the experiment in culture flasks $\left(T-75 \mathrm{~cm}^{2}\right)$ at $2-4 \times 10^{6}$ cell densities, unless stated differently.

\section{Assessment of GD2 Expression in Neuroblastoma Cell Lines}

Neuroblastoma cell lines were studied for GD2 expression levels by flow cytometry. Cells from each cell line were trypsinized and resuspended at a concentration of approximately $4 \times 10^{6}$ cells $/ \mathrm{ml}$ in $10 \mathrm{ml}$ of PBS supplemented $6.6 \%$ FCS and $20 \mathrm{mM}$ EDTA (flow cytometry buffer). Cells were incubated with either anti-GD2 Ab or mouse isotype control $\mathrm{Ab}$ (Thermo Fischer Scientific) as a negative control, at a 1:200 dilution for $45 \mathrm{~min}$ at room temperature. Next, cells were washed three times with flow cytometry buffer by centrifugation for $5 \mathrm{~min}$ at $300 \mathrm{~g}$ and suspended in flow cytometry buffer. After the final washing step, cells were suspended in flow cytometry buffer FACS containing FITC-labeled Goat-antiMouse $\operatorname{IgG}(\mathrm{H}+\mathrm{L}$ ) secondary antibody (Thermo Fischer Scientific) at a dilution of 1:960, followed by incubation at room temperature in the dark for $20 \mathrm{~min}$. Next, the cells were washed as explained above. Gates were set for GD2-positive and negative fluorescence signals, based on the fluorescence intensity obtained from cells as measured by the AccuriTM C6 Flow Cytometer (BD Biosciences, Erembodegem, Belgium). The analysis was based on both living and dead cells. Generally,
10,000 events were acquired per sample. Data were analyzed with CFlow Plus software (BD Biosciences).

\section{Binding and Uptake Studies with Rhodamine Labeled Liposomes}

The binding of rhodamine labeled GD2-targeted and control liposomes to GD2 positive (i.e. IMR32) and GD2 negative (i.e. WiDR) tumor cells was studied by flow cytometry, using an average of $40 \times 10^{3}$ cells $/ \mathrm{ml}$ in flow cytometry buffer. Cells were incubated with liposomes for $1 \mathrm{~h}$ at $4^{\circ} \mathrm{C}$ in the dark at different lipid concentrations ranging from 0.1 to $2 \mathrm{mM}$ TL. Cells were washed three times with FACS buffer as described in the previous section after which mean fluorescence intensity (MFI) of the rhodamine signal was determined using the AccuriTM C6 Flow Cytometer. Generally, 10,000 events were acquired per sample. Data were analyzed with CFlow Plus software.

The uptake of rhodamine-labeled liposomes was studied using KCNR neuroblastoma cells by fluorescence microscopy using a Leica TCS-SP confocal laser-scanning microscope (Leica, Heidelberg, Germany). KCNR cells were seeded at a concentration of $40 \times 10^{4}$ cells $/ \mathrm{ml}$ on FluoroDish ${ }^{\mathrm{TM}}$ glass bottom petri-dishes and allowed to adhere overnight. Cells were incubated with rhodamine labeled liposomes at a TL concentration of $1 \mathrm{mM}$ for $4 \mathrm{~h}$ at $37^{\circ} \mathrm{C}$, followed by washing with cold PBS. Cells were fixed (4\% (v/v) formaldehyde in PBS; 30 $\mathrm{mi}$ at room temperature) and nuclei were stained using Hoechst 33,342 (5 min at room temperature). After washing with cold PBS, the petri-dishes were dried and covered with FluorSave mounting agent and kept at $4^{\circ} \mathrm{C}$ until confocal microscopy analysis. Z-stack of optical sections $(11.5 \mu \mathrm{m}$ in total thickness) was captured with a $20 \times$ objective, using 10 sections with a step size of $1.15 \mu \mathrm{m}$. In order to illustrate cell uptake, 2D images were captured from the middle section of the $\mathrm{Z}$ stack (i.e. 5th section).

\section{In-Vitro Effects of YMI55 Loaded Liposomes}

Efficacy of YM155 loaded liposomes (targeted and nontargeted control liposomes) was studied on KCNR by alamarBlue viability assay (Thermo Fischer Scientific), according to the supplier's instruction. KCNR cells were seeded at $20 \times 10^{3}$ cells/well in 96 well Greiner polystyrene plates (Sigma Aldrich) in complete DMEM medium and allowed to adhere overnight. The medium was replaced by cell culture medium supplemented with YM155 or YM155 liposomal formulations at concentrations ranging from 0.8 to $100 \mathrm{nM}$, after which the cell culture were incubated for $24 \mathrm{~h}$ at $37^{\circ} \mathrm{C}$. Control experiments included incubations with empty liposomes (i.e. without YM155) at equivalent TL concentrations in the range of $0.08-11 \mu \mathrm{M}$ TL. After $24 \mathrm{~h}$ of incubation, medium was replaced with drug-free medium containing alamarBlue reagent $(10 \mathrm{vol} \%$ ), after which cells were 
incubated for an extra $3 \mathrm{~h}$ at $37^{\circ} \mathrm{C}$. Fluorescence was quantified with a microplate reader (Mithras LB940) and used to calculate the relative percentage of living cells normalized against control cells that had not been treated with YM155. $\mathrm{IC}_{50}$ values were calculated by curve fitting using non-linear regression in Graph Pad Prism 6.0.

\section{Pharmacokinetic Pilot Study}

Animal experiments were conducted in compliance with the national regulations and have been approved by the local ethical committee for animal experimentation. NMRI nu/ nu female mice (25 g, Charles River, Massachusetts, USA) were housed in a temperature-controlled room (approximately $22^{\circ} \mathrm{C}$ ) with 55 to $65 \%$ relative humidity, a photoperiod of $12 / 12 \mathrm{~h}$ with free access to water and pelleted rodent food. The mice were challenged with KCNR neuroblastoma (passage 1-2) derived from DAG102776 by serial xenotransplantation in both flanks. When the tumor growth reached the size of approximately $8 \times 8 \mathrm{~mm}$, mice were randomly divided in three groups that were injected intravenously with either free YM155 dissolved in HBS $(1 \mathrm{mg} / \mathrm{kg}, n=11)$, YM155 loaded anti-GD2-immunoliposomes ( $3 \mu \mathrm{mol} \mathrm{TL} / \mathrm{kg}$ diluted in HBS, equivalent to $1 \mathrm{mg} / \mathrm{kg} \mathrm{YM} 155, \mathrm{n}=11$ ), or an equivalent dose of YM155 loaded control liposomes $(\mathrm{n}=11)$. At designated time points (i.e. $5 \mathrm{~min}, 9 \mathrm{~min}, 15 \mathrm{~min}, 30 \mathrm{~min}, 1 \mathrm{~h}, 4 \mathrm{~h}, 8 \mathrm{~h}$, $24 \mathrm{~h}, 48 \mathrm{~h}$ and $72 \mathrm{~h}$ ), blood samples (approximately $0.5 \mathrm{ml}$ per sampling time point) were collected in tubes containing EDTA as anticoagulant and mice were sacrificed. Blood samples and excised tumors were stored at $-80^{\circ} \mathrm{C}$ until analysis of their YM155 concentration by liquid chromatographytandem mass spectrometry (LC-MS/MS) (34).

\section{Pharmacokinetic and Statistical Analyses}

Pharmacokinetic analysis of the in-vivo data was performed using the Pk Solver 2.0 add-in template for Microsoft Excel, as described previously (35). Pharmacokinetic parameters were determined by non-compartmental analysis (NCA) using linear-logarithmic trapezoidal model fitting, or by compartmental analysis (CA) using 1-compartment model fitting.

Statistical significance was analyzed using two-tailed unpaired Student's t-test. A $p$-value $<0.05$ was considered statistically significant.

\section{RESULTS AND DISCUSSION}

\section{Preparation and Characterization of Liposomes}

YM155 loaded liposomes were prepared by drug/lipid film hydration and extrusion, and subsequently purified by three cycles of ultracentrifugation and re-dispersion of the pelletized liposomes in HBS. SATA-modified anti-GD2 was conjugated to the maleimidyl anchor of DSPE-PEG ${ }_{2000}$-Mal before the ultracentrifugation procedure, thus avoiding an additional purification process to remove non-conjugated anti-GD2 from the final immunoliposomes. The physicochemical properties of the different types of liposomes are given in Table II. The average liposome size determined by DLS was in the range of 140-170 nm, with a corresponding polydispersity index of about 0.1 . The prepared liposomes had a slightly negative zeta-potential of around $-10 \mathrm{mV}$. Attachment of anti-GD2 antibody to the surface of the liposomes did not significantly alter their size or surface zeta-potential as compared to control liposomes, and neither did the inclusion of YM155. The average YM155 encapsulation efficiency was found to be around $14 \%$, which is comparable to encapsulation efficiencies of other hydrophilic drugs, resulting in an average loading content of approximately $0.8 \mathrm{mg} / \mathrm{ml}(1.8 \mathrm{mM}$ encapsulated drug, corresponding to a drug/lipid ratio of 0.035 ; see Table II). The reported encapsulation efficiency of $14 \%$ is comparable to encapsulation efficiencies by film hydration method of other hydrophilic drugs Quantification of attached

Table II Physicochemical Properties of Liposomal Formulations Loaded with YMI 55 and/or Containing GD2 Antibody on the Surface

\begin{tabular}{|c|c|c|c|c|c|c|c|c|}
\hline Batch & Size $(n m)$ & PDI & Charge (mV) & $\mathrm{TL}(\mu \mathrm{mol} / \mathrm{ml})$ & Lipid yield (\%) & $\begin{array}{l}\text { Encapsulated } \\
\text { YMI55 }(\mu \mathrm{mol} / \mathrm{ml})\end{array}$ & $\begin{array}{l}\text { Drug / Lipid } \\
\text { ratio }^{\mathrm{a}}\end{array}$ & $\begin{array}{l}\text { YMI } 55 \\
\text { EE }(\%)^{b}\end{array}$ \\
\hline (Empty) control liposomes & $\mid 40 \pm 1$ & $0.10 \pm 0.01$ & $-10.0 \pm 5.2$ & $56.3 \pm 16.6$ & $62.5 \pm 18.4$ & - & - & - \\
\hline $\begin{array}{l}\text { (Empty) anti-GD2 } \\
\text { immunoliposomes }\end{array}$ & $147 \pm 14$ & $0.10 \pm 0.03$ & $-9.0 \pm 1.4$ & $56.6 \pm 22.5$ & $62.8 \pm 24.9$ & - & - & - \\
\hline YMI 55-loaded control liposomes & $|6| \pm 14$ & $0.05 \pm 0.01$ & $-8.1 \pm 2.1$ & $52.7 \pm 13.3$ & $58.7 \pm 11.5$ & $1.85 \pm 0.24$ & $0.036 \pm 0.010$ & $14.3 \pm 4.8$ \\
\hline $\begin{array}{l}\text { YMI 55-loaded anti-GD2 } \\
\text { immunoliposomes }\end{array}$ & $17 \mid \pm 10$ & $0.10 \pm 0.03$ & $-9.6 \pm 0.5$ & $52.5 \pm 14.4$ & $60.2 \pm 12.3$ & $1.77 \pm 0.29$ & $0.035 \pm 0.010$ & $13.9 \pm 5.0$ \\
\hline
\end{tabular}

Data are presented as mean values of 3-5 preparations \pm SD

a Drug/Lipid ratio determined after liposomal disruption. The initial YMI55/Lipid ratio prior to liposomal formulation was determined to be 0.25 , see paragraph 2.2 in main text

b YMI 55 encapsulation efficiency is defined as: [liposomal drug/lipid ratio/ [initial drug/lipid ratio] 
anti-GD2 by microBCA showed an antibody coupling efficiency of around 60\% for both YM155-loaded and empty liposomes, which corresponds to an average of approximately $33 \mu \mathrm{g} \mathrm{Ab} / \mu \mathrm{mol}$ TL. Assuming an average liposomal size of $140 \mathrm{~nm}$, this results in a calculated 16 to 19 antibody molecules coupled per single liposomal particle (see Table III).

To confirm that anti-GD2 had indeed been coupled covalently to the liposomal surface, (i.e. by thioether bond resulting from the reaction of SATA-anti-GD2 with the maleimidylPEG-DSPE lipids) immunoblotting was performed as described in section 2-3. SATA-modified anti-GD2 Ab (SATAGD2) migrated as two bands of approximately 25 and $55 \mathrm{kDa}$, which correspond to the respective light and heavy chains of the antibody (Fig. 2, left). Control (i.e. non-targeted) non-loaded liposomes (L) and control YM155 loaded liposomes (YM155L) did not display any bands, while both GD2-targeted empty (non-loaded) liposomes (GD2-L) and GD2-targeted YM155 loaded liposomes (GD2-YM155-L) displayed several bands between 25 and $80 \mathrm{kDa}$ corresponding to the molecular weight of anti-GD2 Ab heavy or light chains coupled to one or multiple $\mathrm{DSPE}_{-\mathrm{PEG}}{ }_{2000}-\mathrm{Mal}$ anchors (2.9 kDa per unit). Since not all of the anti-GD2 subunits had been modified with SATA and/or conjugated to the maleimidyl-PEG anchor, the immunoliposomal formulations also contained bands that migrated in parallel to the subunits of the parent anti-GD2 protein (i.e. around 25 and $55 \mathrm{kDa}$ ).

\section{Storage Retention and Release of Encapsulated YMI 55 from Liposomes at Different Conditions}

Both liposomal formulations showed good storage stability for at least 3 weeks at $4^{\circ} \mathrm{C}$ in HBS buffer, as reflected in DLS particle size and polydispersity measurements (Supplemental fig. S3A) and YM155 retention (Supplemental Fig. S3B).

The results of the in-vitro release tests of GD2-targeted immunoliposomes and control liposomes loaded with YM155 are shown in Fig. 3. The conditions of the incubation of panel $3 \mathrm{~B}$ were chosen to reflect cell culture or in-vivo conditions $\left(50 \%\right.$ serum, $\left.37^{\circ} \mathrm{C}\right)$, in which effects of either temperature or serum proteins on bilayer stability can be demonstrated. Control and anti-GD2 immunoliposomes released 30.0\%

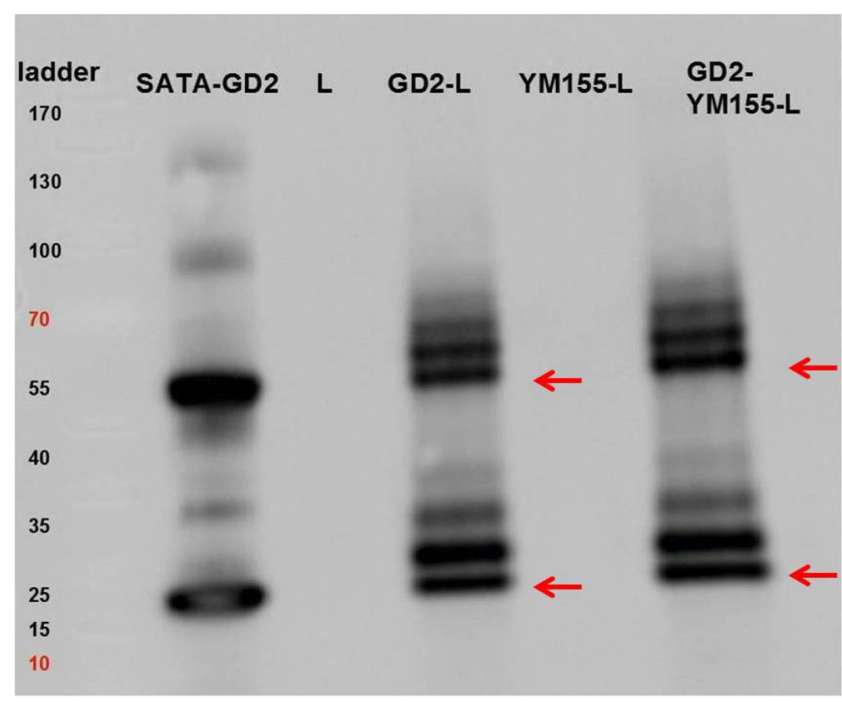

Fig. 2 SDS-PAGE (reducing conditions) of: SATA modified anti-GD2 antibodies (SATA-GD2), empty (YMI55-free) control liposomes (L), empty (YMI55-free) GD2-targeted immunoliposomes (GD2-L), (non-targeted) control YMI 55 loaded liposomes (YMI55-L) and GD2-targeted YMI 55 loaded immunoliposomes (GD2-YMI55-L) from left to right, respectively. Red arrows indicate the location of bands corresponding to antibody subunits not modified with maleimidyl-PEG-DSPE anchor (see also corresponding bands in SATA-GD2) in liposomal formulations. Protein bands with either I or 2 attached PEGylated lipids are clearly visualized at higher MWs. See main text for details.

\pm 11.3 and $34.5 \% \pm 5.2$ of the encapsulated YM155, respectively, over the studied $24 \mathrm{~h}$ time period. The observed leakage of the liposomes could be largely attributed to temperature-related changes in liposomal stability (Fig. 3c, $\mathrm{d}$, showing release in HBS buffer at $37^{\circ} \mathrm{C} v s .4^{\circ} \mathrm{C}$ ) while the presence of either serum albumin or $50 \%$ serum only marginally affected YM155 release (Fig. 3a, b, c showing YM155 release in presence of $5 \% \mathrm{BSA}$ or $50 \%$ serum, versus release in HBS buffer without serum proteins). Comparison of firstorder release rates (Table IV) confirms a slight increase in the YM155 release rate at $37^{\circ} \mathrm{C}$ in the presence of serum albumin. The data in Fig. 3 and Table IV also show that there is no significant difference in YM155 release rate between the control liposomes and the anti-GD2 modified immunoliposomes, regardless of the release medium and temperature. Furthermore, it was shown that the YM155 release
Table III Efficiency of Anti-GD2 Antibody Coupling to Liposomes

\begin{tabular}{lll}
\hline & GD2-YMI55 liposomes & GD2 liposomes (empty) \\
\hline$\mu \mathrm{g} \mathrm{Ab} / \mu \mathrm{mol} \mathrm{TL}$ & $35.7 \pm 9.9$ & $30.9 \pm 9.8$ \\
${\text { Ab coupling efficiency }(\%)^{\mathrm{a}}}^{\text {Ab / liposome }}$ & $60.1 \pm 5.5$ & $58.7 \pm 7.8$ \\
\hline
\end{tabular}

Data are presented as mean values of 3 preparations \pm SD

a Antibody (Ab) coupling efficiency (\%) = (amount of Ab coupled to liposomes/initial amount of Ab added) $\times 100 \%$

b Number of Ab molecules coupled per liposome, assuming all recovered Ab is attached covalently to liposomes, and assuming an average liposome size of $140 \mathrm{~nm}$ 
Fig. 3 Release experiments were performed at different conditions. (a) at $37^{\circ} \mathrm{C}$ in $5 \% \mathrm{BSA}$ in HBS buffer, (b) at $37^{\circ} \mathrm{C}$ in $50 \%$ serum in HBS buffer, (c) at $37^{\circ} \mathrm{C}$ in only HBS buffer and (d) at $4^{\circ} \mathrm{C}$ in 5\% BSA in HBS buffer. Each value represents the mean value $( \pm S . D)$ of two independent experiments performed in duplicate.
YM155 liposomes

a

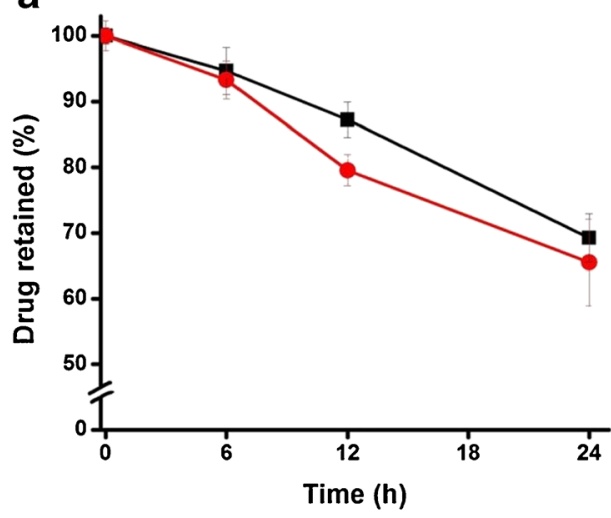

C

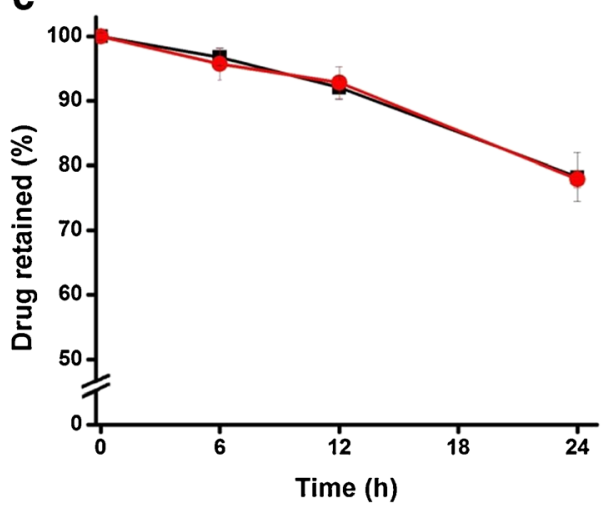

GD2-YM155 liposomes

b

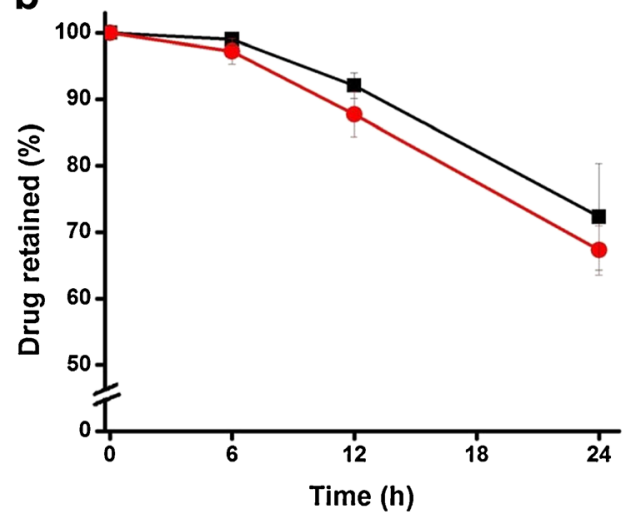

d

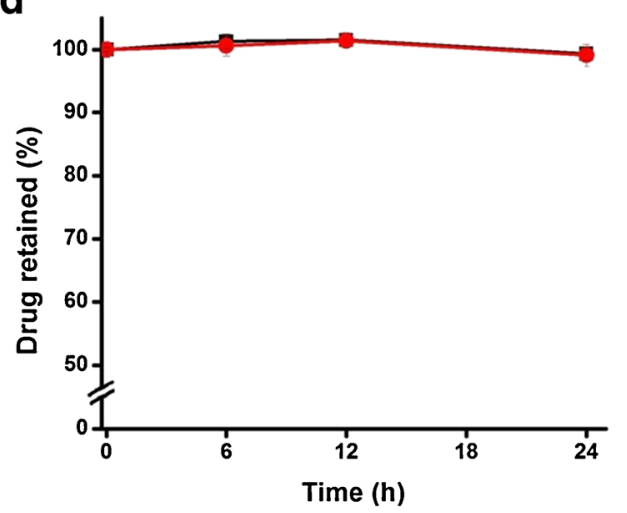

in the presence of HBS buffer $+5 \%$ BSA could be halted for at least $24 \mathrm{~h}$ if the temperature was dropped to $4^{\circ} \mathrm{C}$, as can be seen in Fig. 3d.

A possible explanation for the increased YM155 release at higher temperatures is an increase in fluidity of the lipid bilayer at $37^{\circ} \mathrm{C}(36,37)$. Overall, it can be concluded that YM155

Table IV Comparison of the First-Order Rate Constants $k\left(\mathrm{~h}^{-1}\right)$, Based on Fitting of the in-vitro YMI 55 Release Profiles Shown in Fig. 3, Showing the Effects of Temperature and Medium Composition on the YMI 55 Release Rates

\begin{tabular}{lllll}
\hline \multicolumn{2}{l}{ Conditions } & & & $k\left(\mathrm{~h}^{-1}\right)^{\mathrm{a}}$ \\
\cline { 1 - 1 } Temp. $\left({ }^{\circ} \mathrm{C}\right)$ & Medium & & Control liposomes & Targeted liposomes \\
\hline 37 & $\mathrm{HBS}+5 \% \mathrm{BSA}$ & 0.018 & 0.018 \\
37 & $\mathrm{HBS}+50 \%$ serum & 0.018 & 0.021 \\
37 & $\mathrm{HBS}$ & 0.012 & 0.011 \\
4 & $\mathrm{HBS}+5 \% \mathrm{BSA}^{\mathrm{b}}$ & - & - \\
\hline
\end{tabular}

${ }^{a}$ Value of $k$ equals the slope of the linear fit $\left(R^{2}>0.99\right.$ in all cases) of the semi-logarithmic plot[(YMI55 retained in liposomes) versus time] (not shown), extrapolated from the experimental release profiles shown in Fig. 3a-d

b YMI 55 release from the liposomes in $\mathrm{HBS}+5 \% \mathrm{BSA}$ at $4^{\circ} \mathrm{C}$ remained unchanged ( $<5 \%$ for all samples) during a $24 \mathrm{~h}$ period, indicating the YMI55-containing liposomes are stable in the medium at low temperatures liposomes have moderate stability at body temperature, while neither the presence of proteins (i.e. serum or BSA) in the medium, nor the coupling of anti-GD2 to the liposomal surface appear to greatly influence the stability of the liposomes. The observed release of YM155 from liposomes can be important in the interpretation of other results concerning efficacy and pharmacokinetics, in which free YM155 and encapsulated drug may undergo different uptake and clearance routes. For potential invivo applications of YM155-loaded PEGylated liposomes their instability and the related release of the encapsulated drug is not necessarily problematic, as has been reported by Shakushiro and coworkers (19). In their study, YM155-loaded liposomes with various lipid compositions were extensively studied and tested for antitumor activity. Among the investigated formulations 1,2-distearoyl-sn-glycero-3-phosphocholine/ammonium sulfate (DSPC/AS) liposomes were shown to be the most stable formulation, based on the in-vitro YM155 release study. The YM155 release rate from DSPC/AS liposomes reported by Shakushiro and coworkers (19) is comparable to the YM155 release rate of the formulations described here in the present work. However, Shakushiro et al. reported that the optimal formulation which demonstrated most potent in- vivo antitumor activity was in fact the DSPC/phosphate buffer (BP) liposomes, which showed a relatively higher YM155 in-vitro release rate than the DSPC/AS formulation mentioned earlier. The 
Fig. 4 Binding of liposomal formulations to (a) IMR32 cells and (b) WiDr cells. The data points are aligned (fitted) by non-linear regression (using one phase association model). $\mathrm{MFI}=$ Mean Fluorescence Intensity; $\mathrm{TL}=$ total lipids.

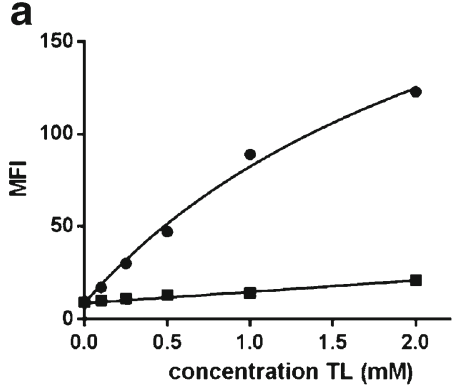

- GD2 targeted labeled lipo

- Control labeled lipo difference in YM155 release rates between the optimum formulations found previously by Shakushiro et al. and the formulations used in this work can be explained by the different nanomedicine targeting approaches in both studies.

Generally, both passively and actively targeting nanomedicine accumulate in the tumor tissue via the enhanced permeability and retention (EPR) phenomenon. When passively targeting nanomedicine accumulates in the target tissue, the encapsulated drug molecules need to be released from their delivery system so that they can be taken up by the target cells. Thus, their release rate needs to be precisely engineered, as described by Shakushiro et al. However, for actively targeting nanomedicine direct endosomal uptake of the nanomedicine is facilitated by the presence of (surface) targeting moieties (e.g. anti-GD2 antibody), which is then followed by cytosolic release of the encapsulated drug molecules. Since this study aims to use actively targeting nanomedicine formulations for the delivery of YM155, the more stable liposomal formulations are expected to be most suitable.

\section{GD2 Expression in Various Neuroblastoma Cell Lines}

GD2 expression levels in neuroblastoma tumor cell lines were measured by flow cytometry as explained in section 2-7. KCNR (and IMR32) neuroblastoma showed relatively high levels of GD2 expression (i.e. about 95\% and 86\%, respectively), while WiDr colon carcinoma cells showed negligible fluorescent signal at the pre-determined gate settings, confirming the lack of GD2 expression on this cell line (data not shown). WiDr cells were further used in flow cytometry experiments as negative control cells.
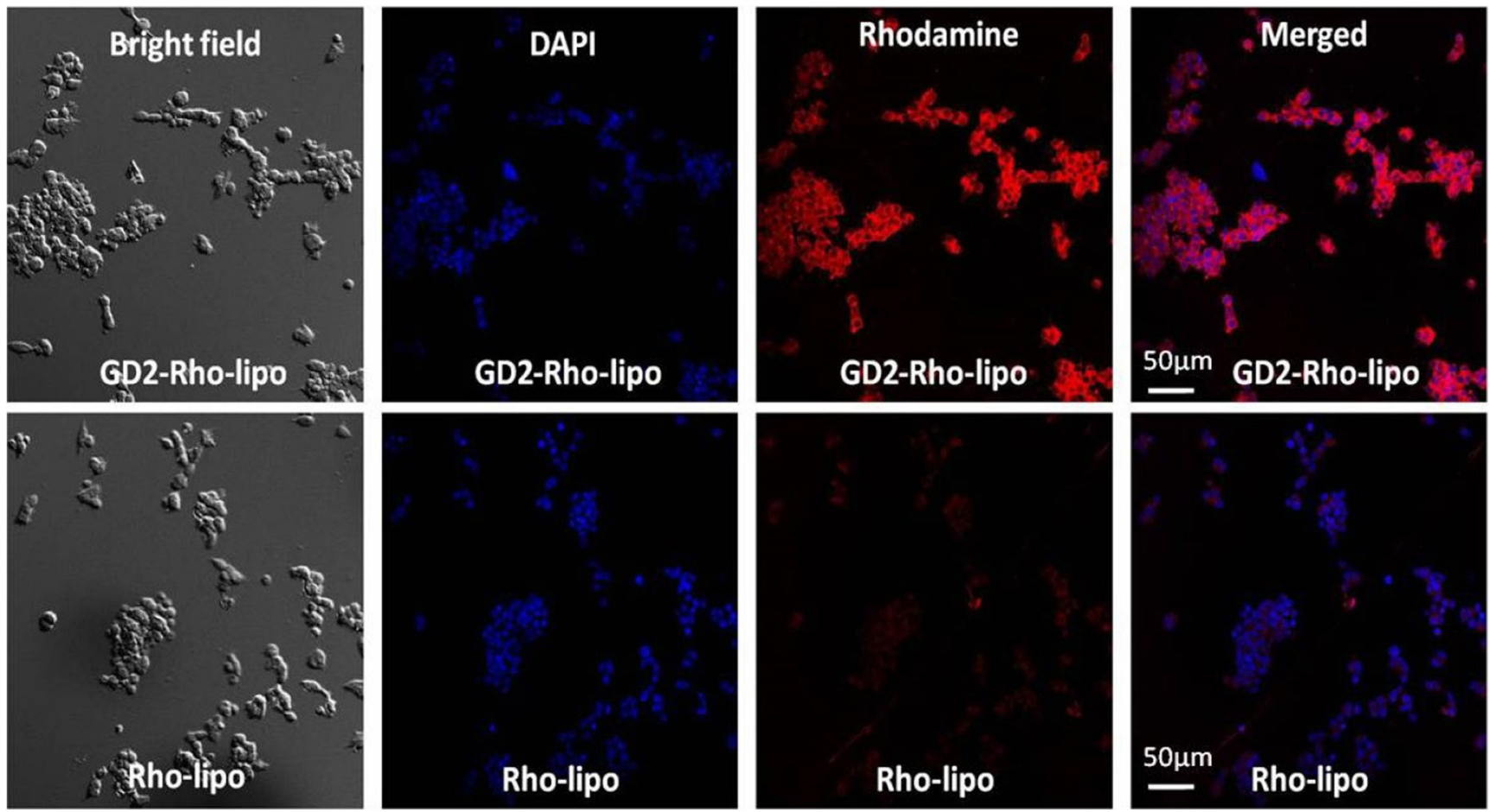

Fig. 5 Confocal laser scanning microscope (CLSM) images of KCNR cells incubated with either GD2-targeted labeled liposomes (GD2-Rho-lipo) or with nontargeted control labeled liposomes (Rho-lipo). Blue staining (DAPI) represents cell nuclei. Red staining (rhodamine) represents liposomes. Scale bars in the figures represent $50 \mu \mathrm{m}$. 


\section{Cell Binding and Uptake of Liposomes}

The ability of GD2-targeted immunoliposomes to recognize GD2 positive cells (IMR32) was demonstrated by incubating rhodamine labeled liposomes with the cells at $4^{\circ} \mathrm{C}$, after which cell-associated liposomes were detected by flow cytometry. A four-fold increase in binding of GD2-targeted immunoliposomes to IMR32 cells was observed in comparison to non-targeted control liposomes (Fig. 4a). Moreover, both formulations showed similar low binding to GD2negative WiDr cells (Fig. 4b), thus confirming the GD2dependency of liposomal binding.

The binding and internalization of GD2-targeted immunoliposomes by KCNR cells was studied by confocal microscopy (Fig. 5). Incubation of cells with liposomal formulation for $4 \mathrm{~h}$ at $37^{\circ} \mathrm{C}$ allowed binding and receptor mediated internalization of immunoliposomes, which was detected by a distinct increase in captured fluorescent intensity at the middle section of z-axis, which was not observed for control liposomes. The obtained results confirm the active (cellular) uptake of GD2-targeted immunoliposomes by KCNR cells.

\section{In-Vitro Evaluation of GD2 Targeted Loaded Liposomes in Cell Culture}

The in-vitro efficacy of YM155 loaded liposomes was studied in KCNR cells by incubating the cells for $24 \mathrm{~h}$ with the developed formulations. Inhibition of survivin by YM155 will change the balance between cell survival and apoptosis, which can be analyzed via analysis of mRNA or surviving protein expression or apoptosis assays, or indirectly by a cell viability assay (AlamarBlue assay). Dose response curves of cell viability experiments are shown in Fig. $6 \mathrm{a}$ and have been analyzed by nonlinear curve fitting to determine $\mathrm{IC}_{50}$ values of each formulation. $\mathrm{IC}_{50}$ values of 27, 60 and $83 \mathrm{nM}$ were calculated for free YM155, anti-GD2 immunoliposomes loaded with YM155, and control liposomes loaded with YM155, respectively. Liposomes not containing YM155 did not induce cell toxicity at the concentrations examined in this work (Fig. 6b). The overall data suggest that treatment of neuroblastoma cells (KCNR) with free YM155 is more effective compared to the treatment of cells with liposomal formulations (targeted or control), although YM155 loaded GD2-targeted immunoliposomes showed an increased (around 20\%) efficacy compared to the non-targeted YM155-loaded control liposomes.

Amphiphilic small molecular inhibitors generally diffuse rapidly through cellular membranes, which enable small molecules to effectively inhibit intracellular molecular targets. However, YM155 is a positively charged small molecule not capable of passive diffusion over lipid membranes. Instead, its intracellular accumulation is actively mediated by cell specific influx transporter channels (38). Apparently, the active uptake of free YM155 is very efficient, outperforming the uptake of immunoliposomes by GD2-positve cancer cells cultured in vitro. The major benefit of encapsulating YM155 in liposomes is however in avoiding its rapid renal elimination, which will be presented below. It should thus be noted that part of the effects observed for the liposomal formulations might be due to a fraction of YM155 that is released from the liposomal formulations during the $24 \mathrm{~h}$ incubation in protein containing cell culture media at $37^{\circ} \mathrm{C}$ and which is subsequently transported over the cell membrane similar to free YM155. However, the absence of sample agitation means that YM155 released from the liposomes during the incubation period is likely to be lower than the corresponding YM155 release in the stability tests shown in Fig. 3. More importantly, the difference in efficacy observed between the anti-GD2 immunoliposomes and the non-targeted control liposomes clearly shows that a significant part of the total YM155 is taken up by the cells while remaining encapsulated in the liposomal nanocarrier system. Figure 7 schematically depicts the available uptake routes of YM155 upon its addition to the cells as liposomal formulation or free drug.
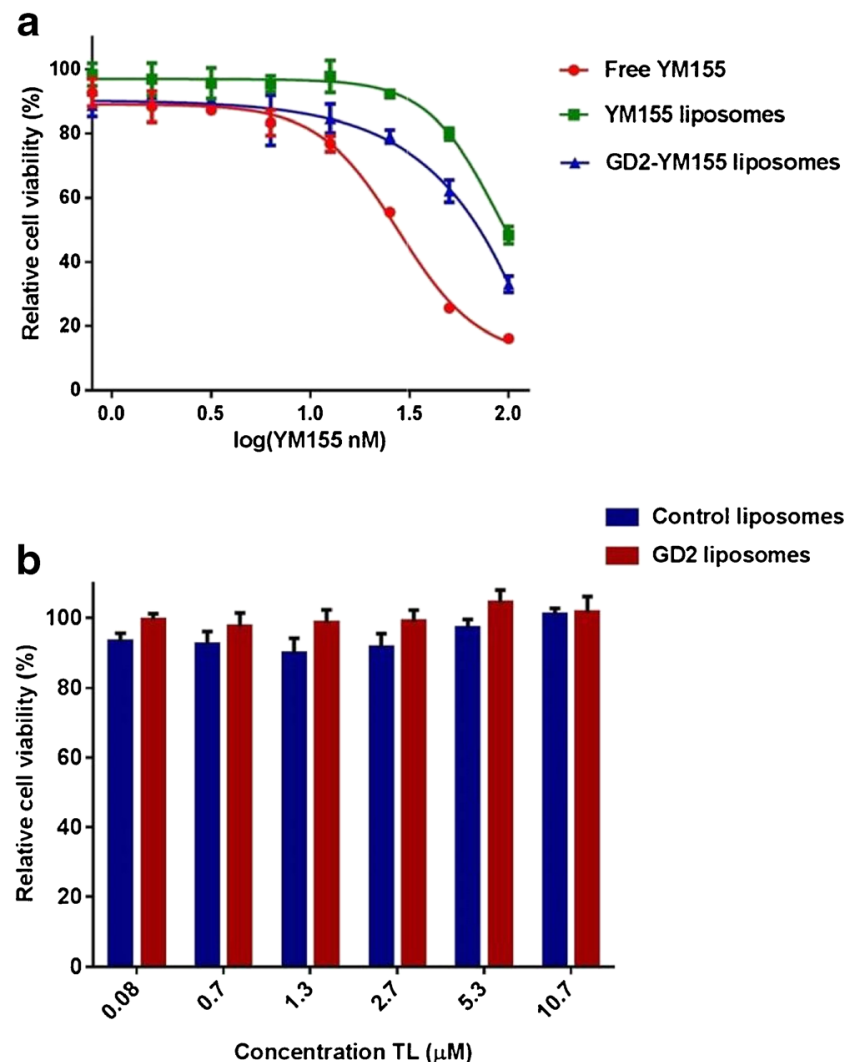

Fig. 6 Cell toxicity was determined in neuroblastoma cells (KCNR) via MTS assay after $24 \mathrm{~h}$ of total incubation period. (a) Semi-logarithmic plot of the cells exposed for $24 \mathrm{~h}$ to YMI 55 loaded liposomal formulations and free YMI 55. The $I_{50}$ values were determined with Graph Pad Prism 6.0. (non-linear regression model was used for curve fitting). (b) Cells were exposed for $24 \mathrm{~h}$ to non-loaded liposomal formulations. Data are plotted as mean values $\pm \operatorname{SEM}(n=3)$. 
Fig. 7 Uptake routes for cytosolic delivery of YMI 55. Receptor mediated uptake delivers GD2targeted YMI 55 liposome into endosomal and eventually lysosomal vesicles. Cytosolic delivery of liberated YMI 55 is facilitated by passive diffusion (possibly as in complex with an organic anion or via organic cation transporters (OCT) when they are present in the lysosomal membrane). Cytosolic delivery of free $\mathrm{YMI} 55$ is facilitated via organic cation transport (OCT) channels at the cell membrane. Adapted with permission from ref. (39). Copyright 2006, Springer.

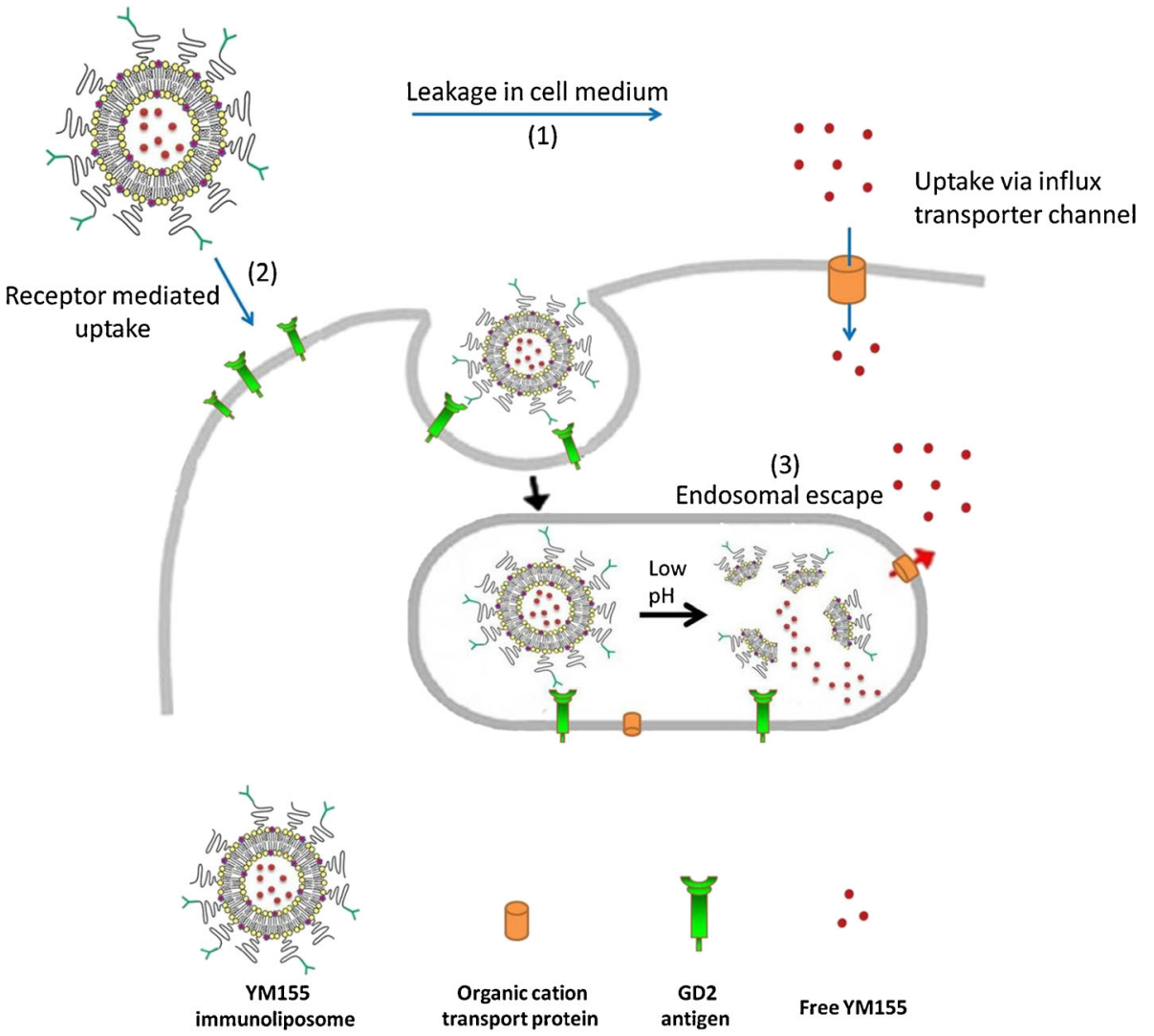

The experiments show no toxicity of the anti-GD2 antibodies attached to the surface of liposomes on KCNR cells. However, toxic effects of free anti-GD2 antibodies were previously reported by Gottstein et al. on IMR32 cells (40). One cause for these alternate observations regarding anti-GD2 toxicity can be the difference in sensitivity of the neuroblastoma cell types (i.e. IMR32 and KCNR) to anti-GD2 antibody. Another explanation is that Gottstein et al. (38) observed toxic effects because in their work the IMR 32 cells were exposed to concentrations of anti-GD2 antibody $\left(\mathrm{IC}_{50} 1.5 \mu \mathrm{g} / \mathrm{ml}\right)$ that were much higher than the concentrations of anti-GD2 antibody that the liposomal surfaces were exposed to in this work. The highest concentration of anti-GD2 (coupled to a liposomal surface) that was added to the cell culture media in our experiments was $0.08 \mu \mathrm{g} / \mathrm{ml}$, which is well below the above mentioned $\mathrm{IC}_{50}$ value of $1.5 \mu \mathrm{g} / \mathrm{ml}$.

\section{Pharmacokinetic Profiles of Free YMI55 and its Liposomal Formulations}

The distribution kinetics of YM155-loaded liposomes was evaluated in nude mice with subcutaneously implanted neuroblastoma tumors. Upon intravenous injection of either targeted or control liposomes or free YM155, plasma and tumor samples were collected over a time period of 5 min till 3 days and analyzed for YM155 by LG-MS/MS. Figure 8 shows the YM155 plasma concentration versus time curves of free YM155 (Fig. 8a), YM155-loaded control liposomes (Fig. 8b), and YM155-loaded anti-GD2 immunoliposomes (Fig. 8c). The calculated pharmacokinetic (PK) parameters for free YM155 and liposomal YM155presented in Table V have been determined by non-compartmental analysis (NCA) using a linear-logarithmic trapezoidal method, in which linear interpolation is used if drug concentrations are increasing or constant $\left(\mathrm{C}_{\mathrm{i}+1} \geq \mathrm{C}_{\mathrm{i}}\right)$, while logarithmic interpolation is used if drug concentrations are decreasing $\left(\mathrm{C}_{\mathrm{i}+1}<\mathrm{C}_{\mathrm{i}}\right)$. The slope of the drug concentration versus time curve in the terminal phase $\left(\lambda_{z}\right)$ was determined by linear regression on a semilogarithmic scale, and $\lambda_{\mathrm{z}}$ was then used to derive pharmacokinetic parameters such as drug half-life $\left(t_{1 / 2}\right)$ and volume of distribution in the terminal phase $\left(\mathrm{V}_{\mathrm{z}}\right)$. PK parameters were also determined by compartmental analysis (CA), in which the YM155 plasma concentration versus time curve is fitted using a 1-compartment model. These fitted data are based on 11-13 animals per group, corresponding to 3-5 time points. Combined with the large error margins in some of the data points, the results from the pharmacokinetic analyses listed in Table V should be treated as estimates when comparing them with pharmacokinetic results from other studies. Within this work however, the PK parameters listed in Table V sufficiently show the differences between the three different formulations (i.e. free YM155, Liposomal YM155, and GD2liposomal YM155). As expected, free YM155 showed a large initial volume of distribution and rapid elimination from the 

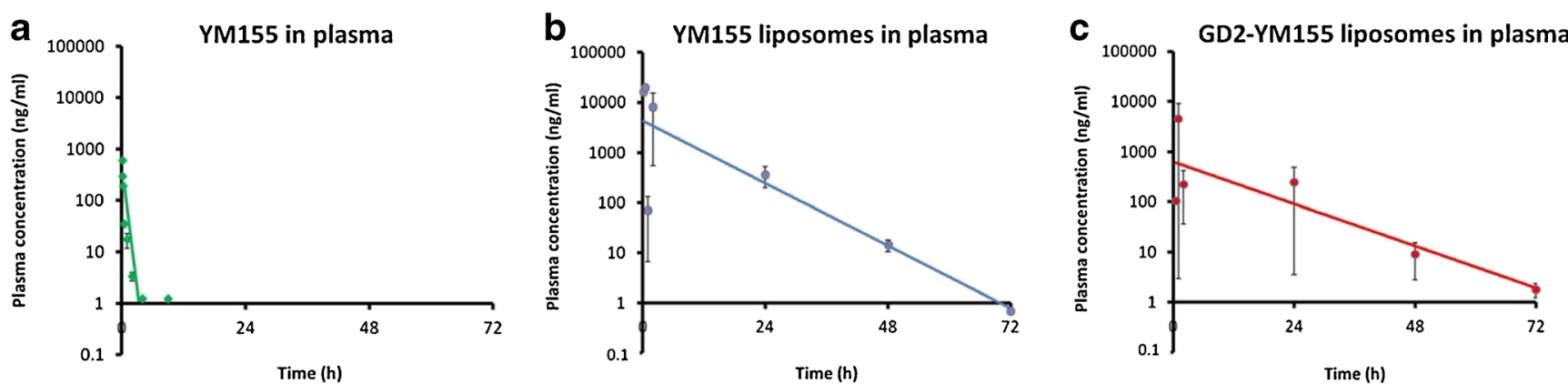

Fig. 8 Semi-logarithmic YMI 55 plasma concentration vs. time plots after single i.v. administration in mice of (a) free YMI 55 (b) liposomal YMI 55 in PEGylated liposomes and (c) liposomal YMI55 in anti-GD2 immunoliposomes. All groups consisted of I I mice and were treated with a dose corresponding to I mg/kg YMI55. Each dataset has been fitted using linear regression (solid lines). In (a) (free YMI 55 in plasma) the data point at $\mathrm{t}=8 \mathrm{~h}$ was excluded to improve the accuracy of the fit. See also Table $V$ and main text.

circulation, resulting in plasma levels that were detectable only for about $8 \mathrm{~h}$ post administration. In contrast, liposomal formulations of YM155 (targeted and control) displayed much smaller distribution volumes as compared to free YM155, which can be expected for PEGylated nanocarriers that are retained within the circulation initially and that only distribute slowly over the endothelial barrier. Moreover, we observed the expected long-circulating properties of PEGylated liposomes, as both formulations were able to sustain elevated plasma levels of YM155 for at least a 3 day time period (Fig. 8b, c, see also Supplemental Fig. S4 for better comparison during the first hours). The increased longevity of liposomal YM155 in blood plasma can be attributed to the small hydrodynamic size of the liposomes and stealth properties provided by PEG chains, which allow liposomal formulations to escape recognition and subsequent clearance by the mononuclear phagocyte system (MPS) (41,42). As long as the drug is still retained in the liposomal nanocarriers, the normal rapid clearance of free YM155 is prevented.

The difference between free YM155 and liposomal YM155 formulations is also clear when examining the pharmacokinetic parameters derived from the NCA fitting model, as listed in
Table V. Clearly, the half-life of free YM155 in blood plasma is shorter $(0.4 \mathrm{~h})$ than that of the control liposomes and the GD2immunoliposomes loaded with YM155 (5.3 and $6.8 \mathrm{~h}$ respectively). These half-life values of the liposomes have been derived from the terminal slope $\left(\lambda_{z}\right)$ of the semi-logarithmic plots above the detection limit. Of note, plasma concentrations of free YM155 had already dropped below detection level at $8 \mathrm{~h}$ and hence only the first few data points (i.e. $t \leq 2 \mathrm{~h}$ ) have been included to calculate the half-life of the free drug. The half-life of YM155 of $0.4 \mathrm{~h}$ is shorter than the previously reported half-life of $\sim 1 \mathrm{~h}(13)$. This may relate to differences in experimental setup or the low number of animals in our study. When comparing YM155 loaded GD2-immunoliposomes to control liposomes, a relative large difference in AUC was observed (1.8 fold higher AUC for control liposomes vs immunoliposomes), which was associated with a relative slower elimination of immunoliposomes. As one would expect initial distribution volumes of both types of liposomes to be similar, and maybe faster clearance of immunoliposomes due to the surface modification with antibodies, we cannot fully explain the differences between the two liposomal formulations. A more detailed study on the distribution and elimination of this type of liposomes seems
Table V Pharmacokinetic Evaluation for Total YMI 55 Levels in Whole Blood after a Single i.v. Administration to Female Mice Bearing Subcutaneous KCNR Tumor Xenografts

\begin{tabular}{llll}
\hline & $\begin{array}{l}\text { Free YMI55 }(2 \mathrm{~h})^{\mathrm{a}} \\
(\mathrm{I} \mathrm{mg/kg})\end{array}$ & $\begin{array}{l}\text { YMI55 liposomes } \\
(\mathrm{I} \mathrm{mg} / \mathrm{kg})\end{array}$ & $\begin{array}{l}\text { GD2-YMI55 liposomes } \\
(\mathrm{I} \mathrm{mg} / \mathrm{kg})\end{array}$ \\
\hline $\mathrm{t}_{1 / 2}(\mathrm{~h})$ & 0.4 & 5.3 & 6.8 \\
$\mathrm{AUC} C_{0-\infty}(\mathrm{ng} / \mathrm{mL} * \mathrm{~h})$ & 136 & 71,473 & 37,787 \\
$\mathrm{C}_{\mathrm{L}}(\mathrm{mL} / \mathrm{h})$ & 7337 & 12 & 26 \\
$\mathrm{~V}_{\mathrm{z}}(\mathrm{mL} / \mathrm{kg})$ & 4653 & 90 & 258 \\
$\mathrm{~V}_{\mathrm{sS}}(\mathrm{mL} / \mathrm{kg})$ & 2466 & 75 & 98 \\
$\mathrm{MRT}_{0-\infty}(\mathrm{h})$ & 0.34 & 6.4 & 3.7 \\
\hline
\end{tabular}

The PK values are calculated by non-compartmental analysis (NCA) using a linear-logarithmic trapezoidal method $C_{0}$, concentration at $t=0$, extrapolated, $t_{1 / 2}=$ elimination half-life; $A \cup C_{0-\infty}$, extrapolated area under the curve from zero to infinity; $C_{L}$, plasma clearance; $V_{z}$, volume of distribution during terminal phase, derived from slope $\left(\lambda_{z}\right)$ in terminal phase; $V_{s s}$, volume of distribution at steady state; $M R T_{0-\infty}$, mean residence time

${ }^{a}$ PK analysis for free YMI 55 is based on data points until $t=2 \mathrm{~h}$. Inclusion of the $\mathrm{t}>2 \mathrm{~h}$ data points will result in an unrealistic estimate of the terminal slope $\lambda_{z}$ (see main text for details) 
Table VI Comparison of Half-Life Values for YMI55 Concentration in Blood Plasma Determined by Non-compartmental (NCA) and Compartmental Analysis (CA)

\begin{tabular}{lll}
\hline & NCA & CA \\
& $\mathrm{t}_{1 / 2}(\mathrm{~h})$ & $\mathrm{t}_{\mathrm{I} / 2}(\mathrm{~h})$ \\
\hline Free YMI55 (2 h) & 0.4 & 0.2 \\
YMI 55 Liposomes & 5.3 & 1.9 \\
YMI55 GD2-Liposomes & 6.8 & 0.2 \\
\hline
\end{tabular}

Half-life values determined by non-compartmental analysis (NCA) using linear-logarithmic trapezoidal model, and compartmental analysis (CA) using a I-compartment model. PKSolver CA model fit parameters, correlation coefficient $\left(R^{2}\right)$ and standard error of weighted residuals (SE): Free YMI 55 (2 h): $R^{2}=0.8 \mathrm{I}, \mathrm{SE}=153(\mathrm{ng} / \mathrm{ml})$; YMI 55 Liposomes: $R^{2}=0.97, \mathrm{SE}=$ 2576 (ng/ml); YMI 55 GD2-Liposomes: $R^{2}=0.99, \mathrm{SE}=142$ (ng/ml).

a PK analyses of free YMI 55 are based on data points until $t=2 \mathrm{~h}$. See also Table $\vee$ and main text

interesting, for instance with labeled liposomes that can be traced immunohistochemically in liver and spleen as these are the main organs responsible for clearance of PEGylated liposomes.

To illustrate the difference in initial and terminal YM155 clearance rates in the different formulations, the pharmacokinetic evaluation was also performed by compartmental analysis (CA), using a 1-compartment model (data not shown). Contrary to NCA, which determines the YM155 half-life from the fitted terminal slope, CA (1-compartment model) fits a first-order exponential decay function to the dataset to determine the PK parameters. The $\left(\mathrm{t}_{1 / 2}\right)$ values of the YM155 concentration in plasma derived from the NCA and CA methods are listed for comparison in Table VI.

It should be noted that the CA used a 1-compartmental model, which means that the fit results are only meaningful for the initial period of rapid decline in YM155 plasma concentration that occurs in the first two hours. Instead, the more gradual decline in the terminal period that can go up to $\mathrm{t}=$ $72 \mathrm{~h}$ is accurately described by the NCA fit results. The difference is most pronounced for the GD2-liposomes loaded with YM155, for which the rapid decrease observed in YM155 plasma concentration during the first $2 \mathrm{~h}$ results in a
CA half-life estimate that is even comparable to that of free YM155 (0.23 and $0.20 \mathrm{~h}$, respectively).

\section{Tumor Accumulation of Free YMI55 and its Liposomal Formulations}

As can be observed in Fig. 9, intratumor levels of YM155 could be detected up to $24 \mathrm{~h}$ post injection for free YM155, or up to three days post injection for liposomal YM155. It is important to notice that free YM155 was eliminated more slowly from tumor tissue than from the circulation which can be attributed to the cation-transporter mediated uptake of the drug into (tumor) tissue and its subsequent intracellular retention. Tumor accumulation of liposomal YM155 was delayed but sustained as compared to free YM155, which can be attributed to accumulation of nanocarriers via leaky tumor blood vessels, i.e. by EPR, and the prolonged residence of the nanocarriers in the circulation (43,44). Moreover, when comparing anti-GD2 immunoliposomes and non-targeted control liposomes, highest intratumoral levels were observed for control liposomes as compare to targeted liposomes $\left(\mathrm{AUC}_{0-\infty}\right.$ values of $13,194 \mathrm{ng} / \mathrm{mL}^{*} \mathrm{~h}$ and $3803 \mathrm{ng} / \mathrm{mL} * \mathrm{~h}$ for control liposomes and anti-GD2 immunoliposomes respectively). The 3.4-fold difference in tumor accumulation cannot be explained fully by the 1.9 fold difference in plasma exposure which should reflect the driving force for tumor uptake by EPR (plasma AUC $71473 \mathrm{ng} / \mathrm{mL} * \mathrm{~h}$ and $37,787 \mathrm{ng} / \mathrm{mL} * \mathrm{~h}$, for control- and anti-GD2 liposomes respectively). Additionally, one may expect a faster uptake by tumor cells of anti-GD2-liposomes via receptor mediated uptake and intracellular processing of anti-GD2 liposomes, which will liberate YM155 from the liposomal carrier. In contrast, control liposomes will be internalized to a lesser extent in the tumor, and YM155 will remain entrapped inside the liposomal vesicles. Although it was not possible in the context of this pilot study, it would also be very interesting to do an additional study comparing the anti-tumor effects of both liposomal formulations, in order to assess the added value of anti-GD2 immunoliposomes over conventional long-circulating PEG-liposomes for the delivery of YM155.
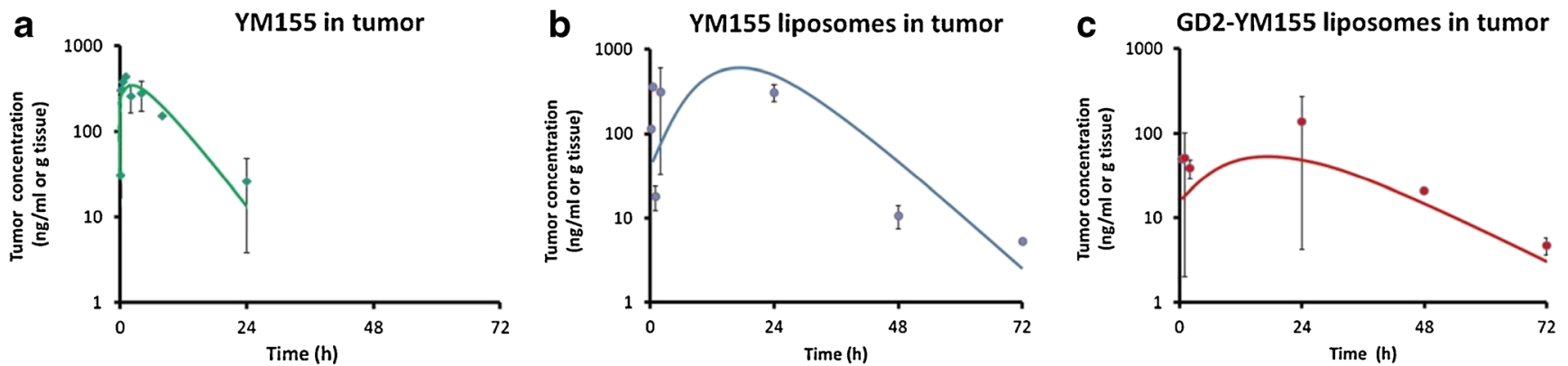

Fig. 9 YMI 55 tumor levels vs. time plots after single i.v. administration of (a) free YMI 55 (b) YMI 55 in PEGylated liposomes and (c) YMI55 in anti-GD2 immunoliposomes. All groups consisted of I I mice and were treated with a dose corresponding to I mg/kg YMI 55. Each dataset has been fitted using linear regression (solid lines). 
Liposomal formulations of YM155 have been previously studied, for example in papers by Kawana et al. (20) and Shakushiro et al. (19). In the study by Kawana and coworkers, the authors developed a liposomal YM155 formulation composed of DSPC, cholesterol and DSPE-PEG 2000 lipids using phosphate buffer as liposomal 'inner' phase. The reported blood circulation half-life $\left(t_{1 / 2}\right)$ was 14.6 and $26.5 \mathrm{~h}$ for YM155 liposomes at a dosage of 3 and $9 \mathrm{mg} / \mathrm{kg}$, respectively (20). In another study by Shakushiro and coworkers, the authors mainly focused on evaluating the effect of different liposomal formulations on the pharmacokinetics and efficacy. They reported $\mathrm{at}_{1 / 2}$ of $24 \mathrm{~h}$ at $3 \mathrm{mg} / \mathrm{kg}$ dose for a liposomal YM155 formulation composed of DPPC, cholesterol and DSPE$\mathrm{PEG}_{2000}$, and $\mathrm{at}_{1 / 2}$ of $48 \mathrm{~h}$ at $3 \mathrm{mg} / \mathrm{kg}$ dose for a formulation composed of DSPC, cholesterol and DSPE-PEG ${ }_{2000}$, both containing phosphate buffer as liposomal inner phase (19). We now observe shorter half-lives of $5.3 \mathrm{~h}$ and $6.8 \mathrm{~h}$ for non-targeted and targeted liposomal YM155 formulations, respectively, which have been determined at relative lower lipid doses, which may have resulted in relative faster clearance of the liposomes.

\section{CONCLUSIONS}

The present study reports on the encapsulation of the survivin inhibitor YM155 in immunoliposomes directed to neuroblastoma cancer cells. Surface bound anti-GD2 antibodies render the liposomes neuroblastoma cell specific (i.e. targeted) which has been confirmed by binding and uptake studies with GD2 expressing tumor cells. Both the immunoliposomes and the non-targeted control liposomes showed similar stability under all conditions, excluding detrimental effects of the surfaceconjugated antibodies on liposome stability. The liposomal formulations were studied in a pilot pharmacokinetic experiment which demonstrated their long-circulating character and capability to accumulate intra-tumor. When compared to free YM155 after single bolus intravenous (i.v.) injection, prolonged intratumoral levels were obtained. A clear added value of using anti-GD2 immunoliposomes could not be assessed in the conducted pilot study. Further studies are required to evaluate the pharmacological effects (efficacy) of YM155-loaded anti-GD2 immunoliposomes at different YM155 dose ranges which may disclose more details on the potential of the liposomal YM155 formulations for clinical therapeutic applications.

\section{ACKNOWLEDGMENTS AND DISCLOSURES}

This work has been supported by NanoNextNL, a micro and nanotechnology consortium of the government of The Netherlands and 130 partners (project 03D.07). The authors would like to thank Charlene Ogu for her helps with characterization of SATA modified anti-GD2 antibody.
Open Access This article is distributed under the terms of the Creative Commons Attribution 4.0 International License (http://creativecommons.org/licenses/by/4.0/), which permits unrestricted use, distribution, and reproduction in any medium, provided you give appropriate credit to the original author(s) and the source, provide a link to the Creative Commons license, and indicate if changes were made.

\section{REFERENCES}

1. Maris JM. Recent advances in neuroblastoma. N Engl J Med. 2010;362:2202-11.

2. Reynolds PC, Hasenhauer B. Treating high-risk neuroblastoma at the turn of the century. ACCO Quarterly Newsletter, Spring 2001. via: http://www.acco.org/wp-content/uploads/2015/03/ ACCO-News-2001-Spring.pdf. Accessed Oct 2017.

3. Morgenstern DA, Baruchel S, Irwin MS. Current and future strategies for relapsed neuroblastoma: challenges on the road to precision therapy. J Pediatr Hematol Oncol. 2013;35(5):337-47.

4. Heck JE, Ritz B, Hung RJ, Hashibe M, Boffetta P. The epidemiology of neuroblastoma: a review. Paediatr Perinat Epidemiol. 2009;23(2):125-43.

5. Rauch A, Hennig D, Schäfer C, Wirth M, Marx C, Heinzel T, et al. Survivin and YM155: how faithful is the liaison? Biochim Biophys Acta. 2014;1845(2):202-20.

6. Lamers F, van der Ploeg I, Schild L, Ebus ME, Koster J, Hansen BR, et al. Knockdown of survivin (BIRC5) causes apoptosis in neuroblastoma via mitotic catastrophe. Endocr Relat Cancer. 2011;18(6):657-68.

7. Lamers F, Schild L, Koster J, Versteeg R, Caron HN, Molenaar JJ. Targeted BIRC5 silencing using YM155 causes cell death in neuroblastoma cells with low ABCB1 expression. Eur J Cancer. 2012;48(5):763-71.

8. Ryan BM, O'Donovan N, Duffy MJ. Survivin: a new target for anti-cancer therapy. Cancer Treat Rev. 2009;35:553-62.

9. Tanioka M, Nokihara H, Yamamoto N, Yamada Y, Goto Y, Fujimoto T, et al. Phase I study of LY2181308, an antisense oligonucleotide against survivin, in patients with advanced solid tumors. Cancer Chemother Pharmacol. 2011;68(2):505-11.

10. Satoh T, Okamoto I, Miyazaki M, Morinaga R, Tsuya A, Hasegawa Y, et al. Phase I study of YM155, a novel survivin suppressant, in patients with advanced solid tumors. Clin Cancer Res. 2009;15(11):3872-80.

11. Zhao X, Puszyk WM, Lu Z, Ostrov D, George T, Robertson K, et al. Small molecule inhibitor YM155-mediated activation of death receptor 5 is crucial for chemotherapy-induced apoptosis in pancreatic carcinoma. Mol Cancer Ther. 2015;14(1):80-9.

12. Tolcher AW, Mita A, Lewis LD, Garrett CR, Till E, Patnaik A, et al. Phase I and pharmacokinetic study of YM155, a small-molecule inhibitor of survivin. J Clin Oncol. 2008;26(32):5198-203.

13. Nakahara T, Kita A, Yamanaka K, Mori M, Amino N, Takeuchi M, et al. YM155, a novel small-molecule survivin suppressant, induces regression of established human hormone-refractory prostate tumor xenografts. Cancer Res. 2007;67(17):8014-21.

14. Minematsu T, Sonoda T, Hashimoto T, Iwai M, Oppeneer T, Felder L, et al. Pharmacokinetics, distribution and excretion of YM155 monobromide, a novel small-molecule survivin suppressant, in male and pregnant or lactating female rats. Biopharm Drug Dispos. 2012;33(3):160-9.

15. Aoyama Y, Katashima M, Sawamoto T. Lack of differences in the pharmacokinetics of sepantronium bromide (YM155) between US 
and Japanese patients with advanced solid tumors or non-Hodgkin lymphoma. Biopharm Drug Dispos. 2013;34(2):137-40.

16. Farokhzad OC, Langer R. Nanomedicine: developing smarter therapeutic and diagnostic modalities. Adv Drug Deliv Rev. 2006;58(14):1456-9.

17. Peer D, KarpJM, Hong S, Farokzhad OC, Margalit R, Langer R. Nanocarriers as an emerging platform for cancer therapy. Nat Nanotechnol. 2007;2:751-60.

18. Bae YH, Park K. Targeted drug delivery to tumors: myths, reality and possibility. J Control Release. 201 1;153(3):198-205.

19. Shakushiro K, Kawano H, Nakata M, Kita A, Meada A, Watanabe $\mathrm{S}$, et al. Formulation design and evaluation of liposomal sepantronium bromide (YM155), a small-molecule survivin suppressant, based on pharmacokinetic modeling and simulation. Pharm Res. 2015;32(1):238-47.

20. Kawano H, Shakushiro K, Nakata M, Kita A, Meada A, Watanabe $\mathrm{S}$, et al. Antitumor efficacy and biodistribution of liposomal sepantronium bromide (YM155), a novel small-molecule survivin suppressant. Eur J Pharm Biopharm. 2014;88(1):283-9.

21. Allen TM, Moase EH. Therapeutic opportunities for targeted liposomal drug delivery. Adv Drug Del Rev. 1996;21:117-33.

22. Lu J, Zhao W, Huang Y, Liu H, Marquez R, Gibbs RB, et al. Targeted delivery of doxorubicin by folic acid-decorated dual functional Nanocarrier. Mol Pharm. 2014;11:4164-78.

23. Mujoo K, Cheresh DA, Yang MH, Reisfeld RA. Disialoganglioside GD2 on human neuroblastoma cells: target antigen for monoclonal antibody-mediated cytolysis and suppression of tumor growth. Cancer Res. 1987;47:1098-104.

24. Schulz G, Cheresh DA, Varki NM, Staffileno LK, Reisfeld RA. Detection of ganglioside GD2 in tumor tissues and sera of neuroblastoma patients. Cancer Res. 1984;44:5914-20.

25. Frost JD, Hank JA, Reaman GH, Frierdich S, Seeger RC, Gan J, et al. Phase I/IB trial of murine monoclonal anti-GD2 antibody 14.G2a plus interleukin-2 in children with refractory neuroblastoma: a report of the Children's cancer group. Cancer Biol Ther. 1997;80:317-33.

26. Uttenreuther-Fischer MM, Huang CS, Yu AL. Pharmacokinetics of human-mouse chimeric anti-GD2 mAb ch14.18 in a phase I trial in neuroblastoma patients. Cancer Immunol Immunother. 1995;41:331-8.

27. Lammie G, Cheung N, Gerald W, Rosenblum M, Cordoncardo C. Ganglioside $\operatorname{gd}(2)$ expression in the human nervous-system and in neuroblastomas - an immunohistochemical study. Int J Oncol. 1993;3(5):909-15.

28. Baiu DC, Artz NS, McElreath MR, Menapace BD, Hernando D, Reeder SB, et al. High specificity targeting and detection of human neuroblastoma using multifunctional anti-GD2 iron-oxide nanoparticles. Nanomedicine (Lond). 2015:1-23.

29. Suzuki M, Cheung NK. Disialoganglioside GD2 as a therapeutic target for human diseases. Expert Opin Ther Targets. 2015;19(3): 349-62.

30. Van der Meel R, Oliveira S, Altintas I, Heukers R, Pieters EH, van Bergen en Henegouwen PM, et al. Inhibition of tumor growth by targeted anti-EGFR/IGF-1R nanobullets depends on efficientblocking of cell survival pathways. Mol Pharm. 2013;7(10):3717-27.
31. Everts M, Koning GA, Kok RJ, Asgeirsdóttir SA, Vestweber D, Meijer DK, et al. In vitro cellular handling and in vivo targeting of Eselectin-directed immunoconjugates and immunoliposomes used for drug delivery to inflamed endothelium. Pharm Res. 2003;20(1):64-72.

32. Rouser G, Fleischer S, Yamamoto A. Two dimensional then layer chromatographic separation of polar lipids and determination of phospholipids by phosphorus analysis of spots. Lipids. 1970;5: 494-6.

33. Adrian JE, Kamps JA, Scherphof GL, Meijer DK, van LoenenWeemaes AM, Reker-Smit C, et al. A novel lipid-based drug carrier targeted to the non-parenchymal cells, including hepatic stellate cells, in the fibrotic livers of bile duct ligated rats. BBA Biomembranes. 2007;1768(6):1430-9.

34. Dolman ME, den Hartog IJ, Molenaar JJ, Schellens JH, Beijnen JH, Sparidans RW. Liquid chromatography-tandem mass spectrometric assay for the light sensitive survivin suppressant sepantronium bromide (YM155) in mouse plasma. J Pharm Biomed Anal. 2014;92:144-8.

35. Gabrielsson J, Weiner D. Non-compartmental analysis. Methods Mol Biol. 2012;929:377-89.

36. Kneidl B, Peller M, Winter G, Lindler LH, Hosann M. Thermosensitive liposomal drug delivery systems: state of the art review. Int J Nanomedicine. 2014;9(1):4387-98.

37. Jones MN, Nicholas AR. The effect of blood serum on the size and stability of phospholipid liposomes. Biochim Biophys Acta. 1991;11165(2):145-1.

38. Iwai M, Minematsu T, Li Q Iwatsubo T, Usui T. Utility of Pglycoprotein and organic cation transporter 1 double-transfected LLC-PK 1 cells for studying the interaction of YM155 monobromide, novel small-molecule survivin suppressant, with Pglycoprotein. Drug Metab Dispos. 2011;39(12):2314-20.

39. Boeckle S, Wagner E. Optimizing targeted gene delivery: chemical modification of viral vectors and synthesis of artificial virus vector systems. AAPS J. 2006;8(4):31-42.

40. Gottstein C, Schön G, Tawadros S, Kube D, Wargalla-Plate UC, Hansmann ML, et al. Anti disialoganglioside ricin A-chain immunotoxins show potent antitumor effects in vitro and in a disseminated human neuroblastoma severe combined immunodeficiency mouse model. Cancer Res. 1994;45(23):6186-93.

41. Hobbs SK, Monsky WL, Yuan F, Roberts WG, Griffith L, Torchilin VP, et al. Regulation of transport pathways in tumor vessels: role of tumor type and microenvironment. Proc Natl Acad Sci U S A. 1998;95(8):4607-12.

42. Maeda $\mathrm{H}, \mathrm{Wu}$ J, Sawa T, Matsumura Y, Hori K. Tumor vascular permeability and the EPR effect in macromolecular therapeutics: a review. J Control Release. 2000;65(1-2):271-84.

43. Maeda H, Sawa T, Konno T. Mechanism of tumor-targeted delivery of macromolecular drugs, including the EPR effect in solid tumor and clinical overview of the prototype polymeric drug SMANCS. J Control Release. 2001;74(1-3):47-61.

44. Immordino ML, Dosio F, Cattel L. Stealth liposomes: review of the basic science, rationale, and clinical applications, existing and potential. Int J Nanomedicine. 2006;1(3):297-315. 